\title{
Synthesis and Characterization of CIS Thin Film Using Chloride Solution
}

\author{
You Guk Lee, Amir Abidov, Sungjin Kim, and Dong Gu Lee
}

\begin{abstract}
In this study, manufacturing cost reduced for CIS precursor solution from chloride series $\mathrm{CuCl}_{2}, \mathrm{InCl}_{3}, \mathrm{GaCl}_{3}$ mixed with acetone solvent without binder was discussed. CIS thin films were coated on a substrate using this precursor solution prepared at normal temperature and pressure by Doctor Blade method. We observed that CIS crystals began to form on the surface at $300^{\circ} \mathrm{C}$ and the surface and internal faults were growing with increasing the temperature. The intensity of main peak increased in CIS absorber layer.
\end{abstract}

Index Terms-CIS thin film, $\mathrm{CuCl}_{2}, \mathrm{InCl}_{3}, \mathrm{SeCl}_{4}$ precursor.

\section{INTRODUCTION}

Current use of fossil fuels appears to be the issue of global warming as a serious problem worldwide. Small power electronic devices or building exterior materials for energy production facility that is used as a way to solve this problem. Solar energy utilization among of other alternative sources has higher interest. Current research is actively conducted in compound solar cells, polycrystalline and amorphous silicon solar cells, dye-sensitized solar cells. Low cost high-efficiency silicon solar cells have to be improved due to drastic decrease in the efficiency at high temperature, such as in desert. Harmful to human health due to the use of $\mathrm{Cd}$ pretreatment are stable CdTe thin-film solar cell. All of these problems can be overcome in $\mathrm{CuInSe}_{2}$ thin film solar cells developed before have recently been spotlighted, and many studies are underway [1], [2]-[5]. $\mathrm{CuInSe}_{2}$ has direct transition type band gap, and compared different optical absorption compounds and $1 \times 105 \mathrm{~m}-1$ 's high optical absorption coefficient $\mathrm{c}, \mathrm{Ga}, \mathrm{Al}, 3$ foot by 6 foot or the addition of elemental $\mathrm{S}$ of the optical band gap to $1.0 \mathrm{e} \mathrm{V}$ $1.7 \mathrm{~V}$ e scope of control can determine the Chalcopyrite I-III-VI stepped into the compound of the two thin-film solar cells is as effective substances from optical absorption layer [6], [7]. VI 2 Chalcopyrite crystal structure of the family as the gap can be adjusted in the range of $1.0 \mathrm{eV} \sim 2.7 \mathrm{eV}$ optical absorption in thin-film solar cell layer is an effective substance [6], [7]. CdS Heterojunction with solar cells as a form of $\mathrm{CuInSe} 2$ thin films have excellent characteristics, such as the optical absorption layer of solar cells can be prepared. Such a method of manufacturing optical absorption

Manuscript received February 17, 2013; revised March 30, 2013. This paper was supported by Research Fund, Kumoh National Institute of Technology.

Dong Gu Lee is the corresponding author.

The authors are with the Department of Advanced Materials Engineering, Kumoh National Institute of Technology, Deahak-Ro 61, Gumi, Gyeongbuk 730-701, Korea (e-mail: size4color@empas.com, abidov_kit@yahoo.com, sjghim@nate.com, dglee@kumoh.ac.kr). layer of $\mathrm{CuInSe}_{2}$ simultaneous vacuum evaporation process, selenization process, electrolytic deposition, sputtering, etc. [8], [9]. In this study, $\mathrm{CuInSe}_{2}$ precursor solution was made by Doctor Blade Chloride series of $\mathrm{CuCl}_{2}, \mathrm{InCl}_{3}, \mathrm{SeCl}_{4}$ by viscosity, which acts as a binder without forming a thin film. $\mathrm{CuInSe}_{2}$ precursor produced by toxic gas selenization process $\mathrm{CuInSe}_{2} \mathrm{GaCl}_{3}$ addition to uncovering the mechanism for the formation of thin film due to the change in temperature of the $\mathrm{Ga}$, In some substitution by $\mathrm{In} / \mathrm{Ga}$ composition-specific synthetic according to the decision and to understand the change of the band gap energy.

\section{EXPERIMENTAL METHODS}

\section{A. Boards and CIS Precursor Solution Manufacturing}

Soda Lime Glass (SLG) substrate used in the experiment was about $3 \times 3 \mathrm{~cm}$ size. After cutting substrate was cleaned ultrasonically in acetone and ethanol, and ultrapure water for 10 minutes respectively to remove organic matter and minerals from surface each substrate was dried with $\mathrm{N}_{2}$ gas. Process is shown in Fig. 1.

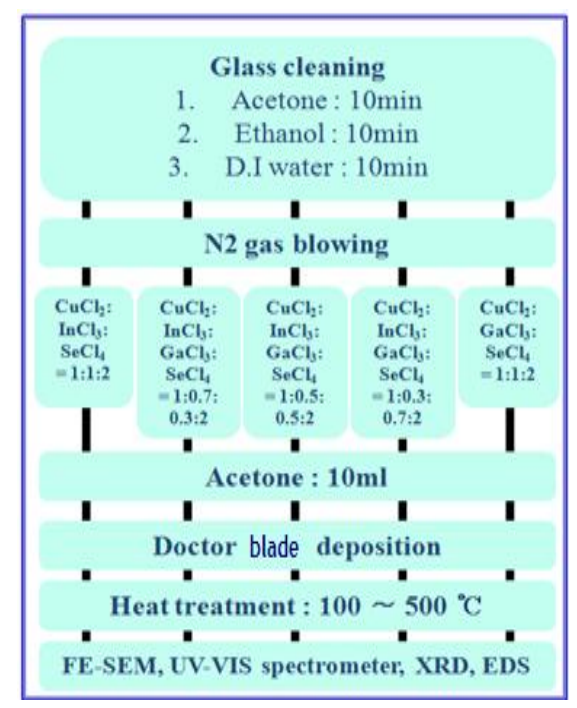

Fig. 1. Acetone-based precursor paste containing CIS precursors.

In order to prepare the precursor solution was made. Molar concentrations of $\mathrm{CuCl}_{2}, \mathrm{InCl}_{3}, \mathrm{SeCl}_{4}$ were mixed according to ratio 1:1:2 and placed in a beaker containing Acetone. Precursor solution was covered with parafilm to minimize evaporation. Solution was stirred for 1 hour using magnetic stirrer. Further parafilm was removed and solution was stirred for 1 hour to reach necessary viscosity. Resultant black colored viscous solution is obtained. In this experiment, the high soluble $\mathrm{CuCl}_{2}, \mathrm{InCl}_{3}, \mathrm{SeCl}_{4}$ chloride series of metals sources were used. Binder to maintain the viscosity of the precursor solution usually should be added. 
not evaporate completely after the heat treatment. It may present as impurities in crystal growth. Cost savings can be improved by eliminating the binder itself. Therefore, in this experiment, viscous CIS precursor by evaporation of solvent under atmospheric pressure at room temperature in a reasonable amount of time, and without binder is reported. CIS thin films on substrate were achieved by Doctor blade method with further heat treatment process.

\section{B. CIS Precursor Solution Deposition}

Forming a thin film on a substrate from manufactured precursor solution was achieved by Doctor blade method. Thickness of thin film formed on the substrate can be adjusted by viscosity of precursor solution. Scotch tape was applied on the specific desired area of substrate. Precursor was spread on bare surface and further useless amount of precursor was removed by blade. After coating scotch tape was removed

\section{Heat Treatment of CIS Thin-Film}

In order to control of amount selenium in $\mathrm{SeCl} 4$ precursor solution during formation CIS thin film it is necessary to provide of Se ions by a treatment under $\mathrm{H} 2 \mathrm{Se}$ gas before making evaporation in CIS thin films.

The process of formation of CIS film is shown in Fig. 2.

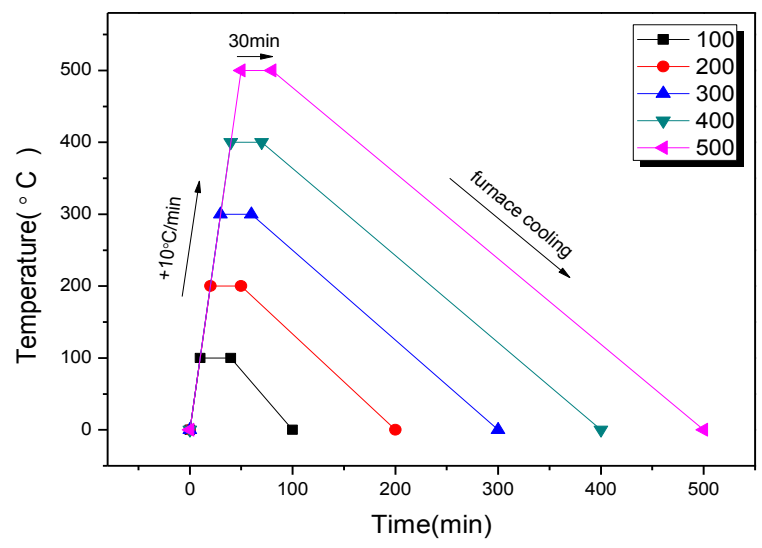

Fig. 2. Temperature ranges of the heat treatment.

The experiment was carried out on CVD quartz tube with inner diameter $66 \mathrm{~mm}$ and length $1000 \mathrm{~mm}$. The substrate pressure was 20mTorr controlled by rotary pump without additional gas flow and for prevention of evaporation lost at high vacuum pressure the maximum heating rate was equal $10{ }^{\circ} \mathrm{C} / \mathrm{min}$ for making reacting compounds from $\mathrm{Se}, \mathrm{Cu}$, In. If thermal treatment in CVD heating zone continued $30 \mathrm{~min}$ it lead to appearance of cracks, therefore for uniform re-crystallization we used the slow cooling process during 1 hour. Surface and microstructure characterization of synthesized CIS samples were carried out by FE-SEM (JEOL, JSM-6500F) and XRD (Rigaku, SWXD), EDS (JEOL, JSM-6500F), UV-Vis (Perkin Elmer, Lambda 950) and determinism, measurement of absorbance.

\section{RESULTS AND DISCUSSION}

The XRD peak intensity changed through of the precursor solution is seen as the $\mathrm{CuCl}_{2}, \mathrm{InCl}_{3}$ and $\mathrm{SeCl}_{4}$ mixed amorphous thin film is shown in (Fig. 3).

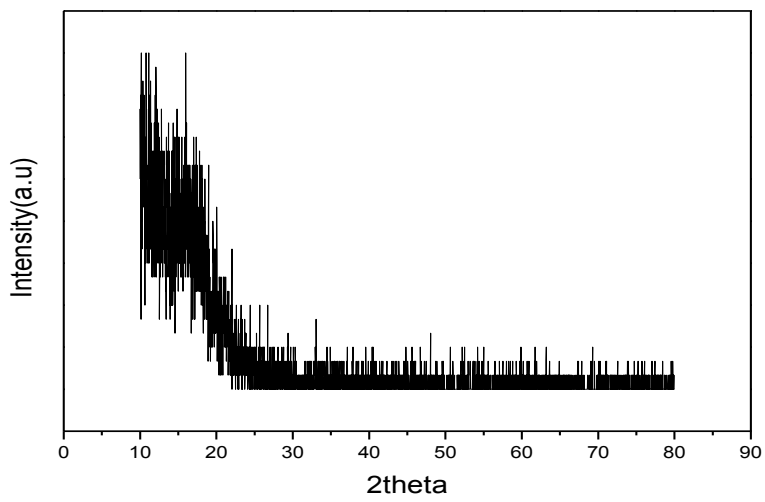

Fig. 3 XRD of CIS thin films.

This obtained amorphous thin film, as shown from FE-SEM image precursor solution with $\mathrm{Cu}$, In, Se thin film forms like island and mixed substance surface of the thin film shown in (Fig. 4).

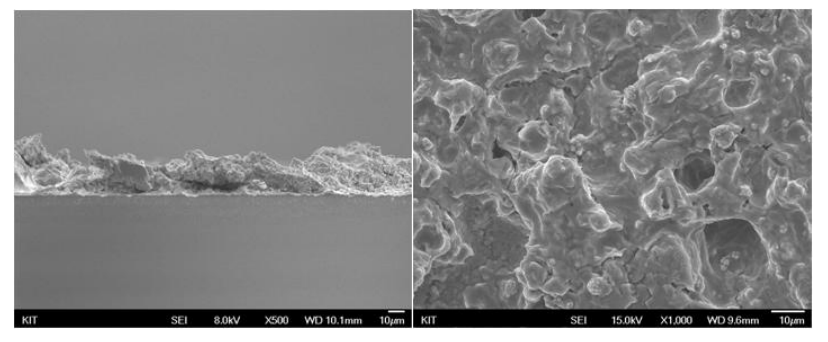

Fig. 4. FE-SEM images of precusor CIS thin film.

This mixed $\mathrm{SeCl}_{4}, \mathrm{CuCl}_{2}$ and $\mathrm{InCl}_{3}$ materials solvent soluble in acetone, $\mathrm{CuCl}_{2}$ and $\mathrm{InCl}_{3}$ contains a lot of mixed substances $\mathrm{SeCl}_{4}$ relatively thin film in the coating, made fodder. Precursor solution CIS coatings depending on the changes of temperature and heat treatment after curing black color thin film is seen with the naked eye when since losing the color black gray at $300{ }^{\circ} \mathrm{C}$ has changed, this is metal ions than the relatively much less the amount of the solvent acetone existed $\mathrm{CuCl}_{2}, \mathrm{InCl}_{3}, \mathrm{SeCl}_{4}$. FE-SEM survey at increasing temperature each 30 minutes in the processing of thin film thickness is reduced, you can see (Fig. 5), less than the initial precursor thin film on the surface, at $100{ }^{\circ} \mathrm{C}$ roughness can be seen better.

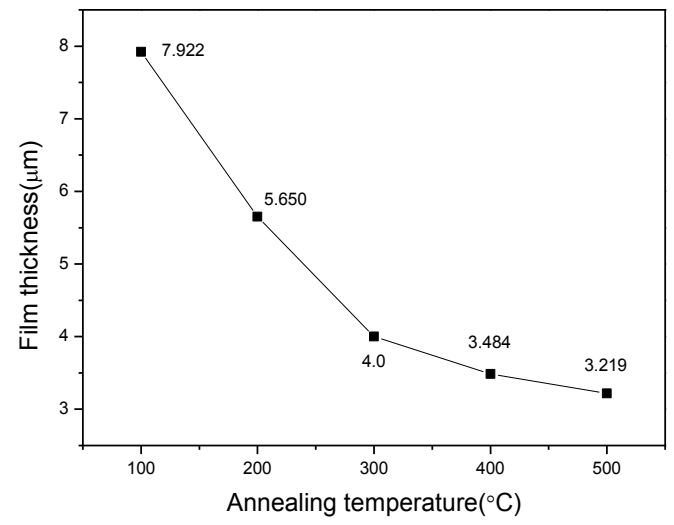

Fig. 5. Thickness of CIS thin film at different heat treatment temperature.

This is the boiling point and evaporation at low Acetone solvents, while weight reduction due to the feed. At $200{ }^{\circ} \mathrm{C} \mathrm{Cu}$, In and Se ions in decisions if the hole in the layer invisible and you can see that this is a precursor to dissolve due to the 
evaporation of $\mathrm{Cl}$ ion as fodder. At $300{ }^{\circ} \mathrm{C}$ weight reduction of the precursor decomposition has been happening on the surface of $\mathrm{Cu}$, In and Se determines this by with ions can see to get out, and the overall surface at $400{ }^{\circ} \mathrm{C} . \mathrm{Cu}$, in and Se ions are determined also the faults of this evenly shaped island made the decision to get out remains to be seen. At $500{ }^{\circ} \mathrm{C}$ the surface monolayer island shaped $\mathrm{Cu}$, In and $\mathrm{Se}$, the decisions of a thin film of beating the larger ions in many parts of the decision upset that we can see (Fig. 6).
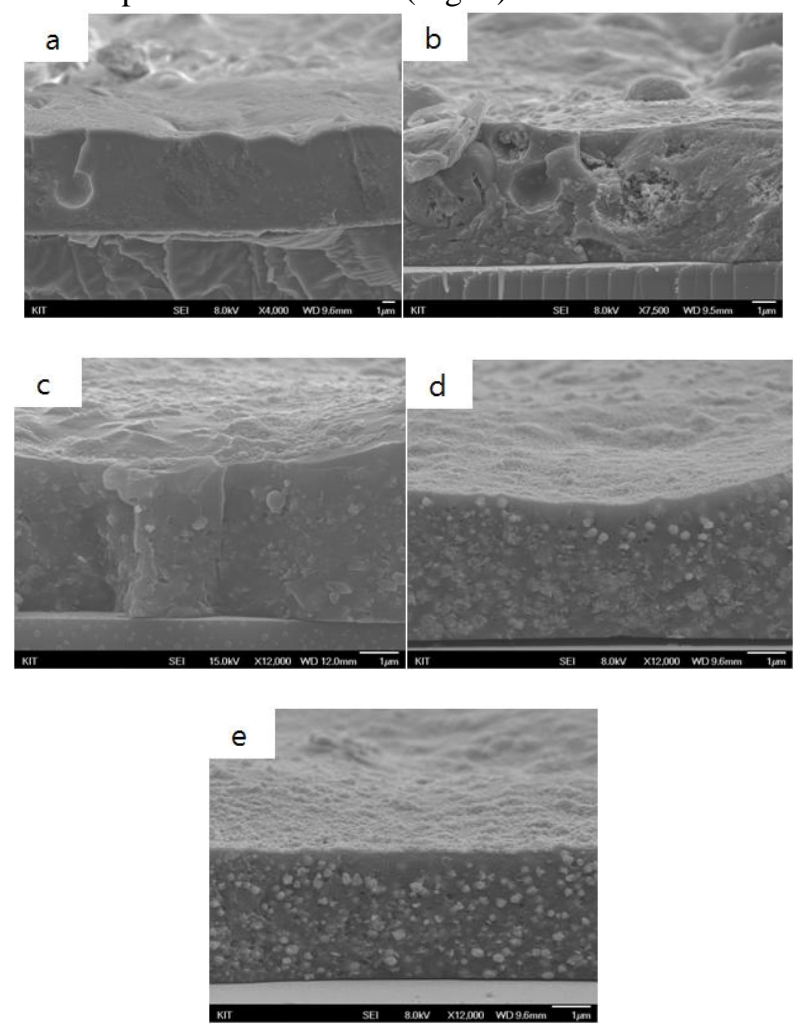

Fig. 6. FE-SEM images of CIS thin film at different heat treatment temperature. (a) $100^{\circ} \mathrm{C}$, (b) $200{ }^{\circ} \mathrm{C}$, (c) $300^{\circ} \mathrm{C}$, (d) $400^{\circ} \mathrm{C}$, (e) $500^{\circ} \mathrm{C}$.

If you look at the results of $\mathrm{Cl}$ ion EDS is 100 to $200{ }^{\circ} \mathrm{C}$ shows slowly decreasing and decreased sharply by $4.42 \%$ from $300{ }^{\circ} \mathrm{C}$ to $400{ }^{\circ} \mathrm{C}$ and $500{ }^{\circ} \mathrm{C}$ and 0.98 to $1.08 \%, 400{ }^{\circ} \mathrm{C}$ in temperature after the $\mathrm{Cl}$ ion is the least amount of CIS decisions by ensuring the presence of impurities do not exist as you can see (Fig. 7).

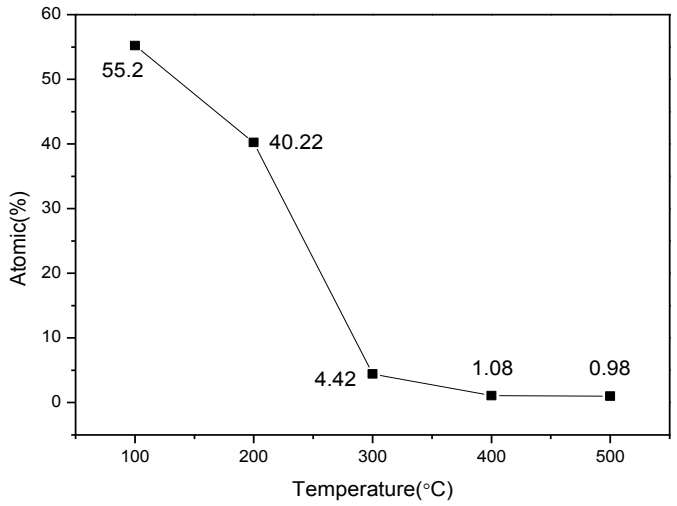

Fig. 7. Chlorine atomics by CIS thin film at different heat treatment temperature.

Also in the vicinity of 50 to $60{ }^{\circ} \mathrm{C}$ at TGA weight begins to decrease and to be reduced up to $100{ }^{\circ} \mathrm{C}$, which is volatile evaporate the solvent acetone in fodder and $100{ }^{\circ} \mathrm{C} \sim 200{ }^{\circ} \mathrm{C}$ precursor evaporation of the solvent acetone and until decomposition happens becomes fodder for a reduction in weight that occur. From $200{ }^{\circ} \mathrm{C}$ to $400{ }^{\circ} \mathrm{C}$, until FE-SEM and as you can see through the EDS precursor decomposition happens continuously, a weight reduction of the evaporation of the $\mathrm{Cl}$ feed (Fig. 8).

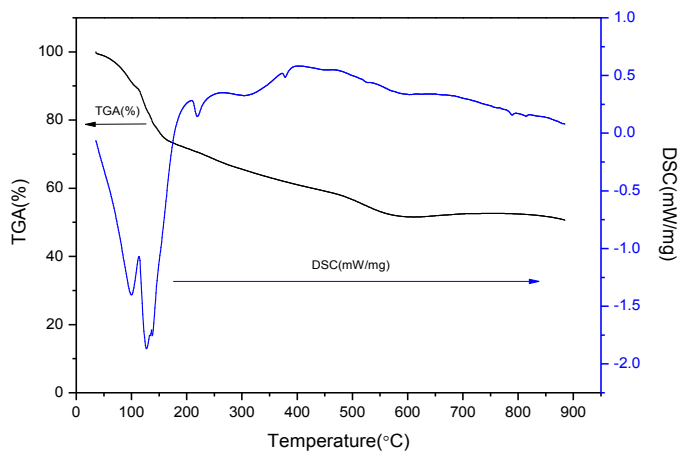

Fig. 8 TGA/DSC analysis to the annealing temperature.

$\mathrm{CuCl}_{2}$ crystallization from a low broad peak at $15.88^{\circ} \mathrm{C}$ appears when the film heat treated at $100^{\circ} \mathrm{C}$, and other substances in the peak did not appear. This means that the fragmentation of acetone evaporation occurred at $100^{\circ} \mathrm{C}$, which, can be seen from the results of the TGA analysis of [JCPDS-791635]. At $200^{\circ} \mathrm{C} \mathrm{CuCl}_{2}$ peak was disappeared and $\mathrm{Cu} 2 \mathrm{Se}$ peak was appeared, which is considered the $\mathrm{CuCl}_{2}$ precursor decomposition [JCPDS-831814]. Determined directions of chalcopyrite structure (112), (220)/(204), (311)/(116) In $2 \mathrm{Se} 3$ and $\mathrm{Cu} 2 \mathrm{Se}$ peaks were observed at $300^{\circ} \mathrm{C}$. Form of metal chalchogenide $\mathrm{Cu}_{2} \mathrm{Se}$ predominantly existed inside thin-film metal chloride, selenium chloride precursor of $\mathrm{Cu}$ In Se through reacting with In than $\mathrm{Cu}$ in the peak was found. Due to the evaporation of Se source in used In-Selenization process revealed in in-situ XRD analysis. The mechanism of crystal growth can be seen in several papers [10], [11]. Also can be seen the decomposition of the precursor from $100{ }^{\circ} \mathrm{C}$ from $200{ }^{\circ} \mathrm{C}$ at $100{ }^{\circ} \mathrm{C}, \mathrm{CuCl}_{2}$ peak cannot be seen. $\mathrm{CuCl} 2$ existed until $300^{\circ} \mathrm{C}$ In $2 \mathrm{Se}$ peak disappears at temperature over $400^{\circ} \mathrm{C}$.

From $500^{\circ} \mathrm{C}$ only CIS determined crystal structure direction of chalcopyrite preferred orientation appears (see Fig. 9).

Whereas maintaining $\mathrm{Cu}$ : $\mathrm{In}: \mathrm{Se}$ ratio of $1: 1: 2$ the concentration of each precursor $0.2 \mathrm{M}: 0.2 \mathrm{M}: 0.4 \mathrm{M}$, changed to $0.4 \mathrm{M}: 0.4 \mathrm{M}: 0.8 \mathrm{M}$ difference were examined.

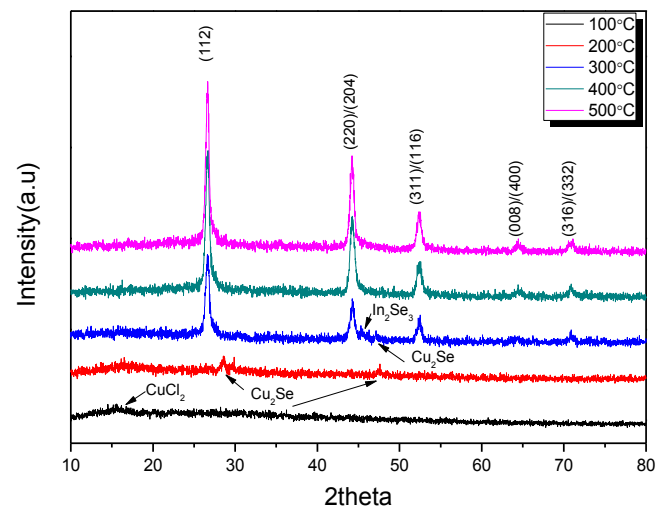

Fig. 9. XRD patterns of the CIS thin film annealed at various temperature.

When precursor concentration increases, the size of CIS determined to be larger (Fig. 10). It also was confirmed that 
the island growth promotes if you use a relatively high concentration of precursor solution. CIS Grain by grain growth accelerated, forming a thin film on the substrate as a whole as the CIS's main peak, (112), (204) / (220), you can see a tendency to increase (312) / (116) intensity. When the heating temperature is increasing with an increase of concentration, precursor diffuses to the surface, increasing the amount of CIS thin film which is determined by the number and size of grain size.
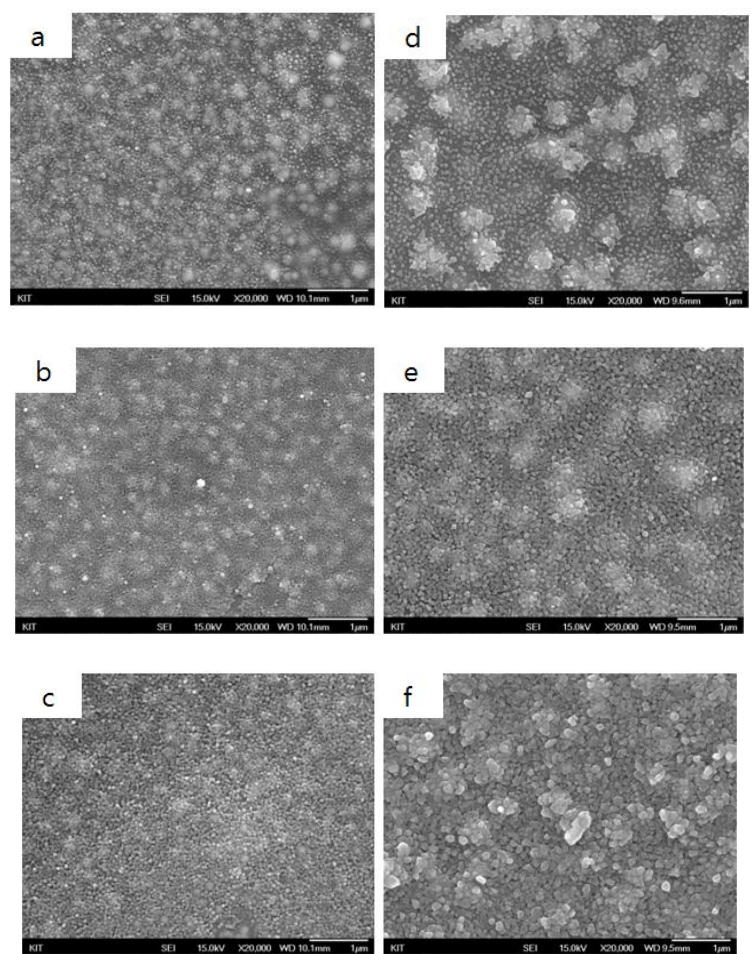

Fig. 10. FE-SEM images of CIS thin films at temperature and composition (a) $300^{\circ} \mathrm{C} 0.2 \mathrm{M}: 0.2 \mathrm{M}: 0.4 \mathrm{M}$, (b) $400^{\circ} \mathrm{C} 0.2 \mathrm{M}: 0.2 \mathrm{M}: 0.4 \mathrm{M}$, (c) $500^{\circ} \mathrm{C}$

0.2M:0.2M:0.4M (d) $300^{\circ} \mathrm{C}$ 0.4M:0.4M:0.8M, (e) $400^{\circ} \mathrm{C}$ 0.4M:0.4M:0.8M, (f) $500^{\circ} \mathrm{C} 0.4 \mathrm{M}: 0.4 \mathrm{M}: 0.8 \mathrm{M}$.

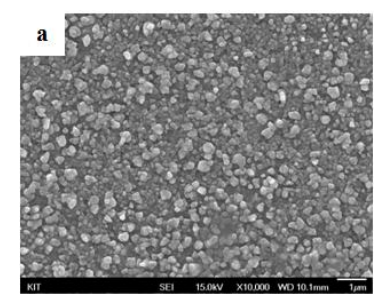

Fig. 11. FE-SEM images of CuInSe 2

XRD full width at half maximum (FWHM: Full Width at Half Maximum) of the CIS increased when temperature grew up. [JCPDS-872265] CIS Intensity ratio of the (112) and (204) / (220) is $100 / 65$. The ratio of heat-treated specimens at (112), (204) / (220) was measured. Intensity ratio of CIS sample (0.2M: $0.2 \mathrm{M}: 0.4 \mathrm{M}$ ) at $300{ }^{\circ} \mathrm{C}$ is $100 / 41$ and $100 / 44$ at $500{ }^{\circ} \mathrm{C}$. Another CIS sample (0.4M: $0.4 \mathrm{M}: 0.8 \mathrm{M})$ at $400{ }^{\circ} \mathrm{C}$ performed $100 / 45$ at $300{ }^{\circ} \mathrm{C} 100 / 44$ at $400{ }^{\circ} \mathrm{C} 100 / 52,500{ }^{\circ} \mathrm{C}$ in the 100/54 were obtained (Table I). It can be seen that the CIS composition and temperature increases, the intensity ratio of the [JCPDS-872265] matches that growth. Therefore, within the solubility limit as much as possible increasing concentration of precursor to obtain larger grain thin films Intensity ratio of the value (112) and (204)/(220) increases JCPDS-872265.
TABLE I: FWHM AND DETERMINE DIRECTION RATION OF CIS THIN FILMS AT VARIOUS TEMPERATURE AND COMPOSITION.

\begin{tabular}{ll|l|l|l}
\hline \hline \multirow{2}{*}{} & \multicolumn{2}{c|}{ CIS(0.2M:0.2M:0.4M) } & \multicolumn{2}{l}{ CIS(0.2M:0.2M:0.4M) } \\
\cline { 2 - 5 } & FWHM & $\begin{array}{l}(112),(220) /(204) \\
\text { ratio }\end{array}$ & FWHM & $\begin{array}{c}(112),(220) / \\
(204) \text { ratio }\end{array}$ \\
\cline { 2 - 5 } $300^{\circ} \mathrm{C}$ & 0.62184 & $100 / 41$ & 0.58549 & $100 / 44$ \\
\hline $400^{\circ} \mathrm{C}$ & 0.55509 & $100 / 44$ & 0.54561 & $100 / 52$ \\
\hline $500^{\circ} \mathrm{C}$ & 0.54855 & $100 / 45$ & 0.50408 & \\
\hline \hline
\end{tabular}

Absorbance of optical energy band gap was measured by UV-Visible spectrophotometer. In this study, UV-Vis NIR spectrometer (Perkin Elmer, Lambda 950) using the extrinsic region of visible light - 400nm $\sim 2300 \mathrm{~nm}$ near-infrared single absorbance was measured. Measured absorbances were converted to a direct bandgap in semiconductors using equation (1).

$$
\alpha h v=B\left(h v-E_{0}\right)^{\frac{1}{2}}
$$

Where, alpha is the absorption coefficient, B is a constant, $h v$ is Photon energy and Eo is the energy band gap. Changes in energy band gap of CIS samples (0.4M: $0.8 \mathrm{M})$ heat treated at $500{ }^{\circ} \mathrm{C}$ were examined in order to obtain the value of $\mathrm{Ga}$, In etc [12]. If you substitute $\mathrm{Eg}$ of $\mathrm{CuInSe} 2(1.23 \mathrm{eV})$, it will show that the maximum efficiency is ideal $\mathrm{Eg}$ value, slightly less than the value $(1.43 \mathrm{eV})$.

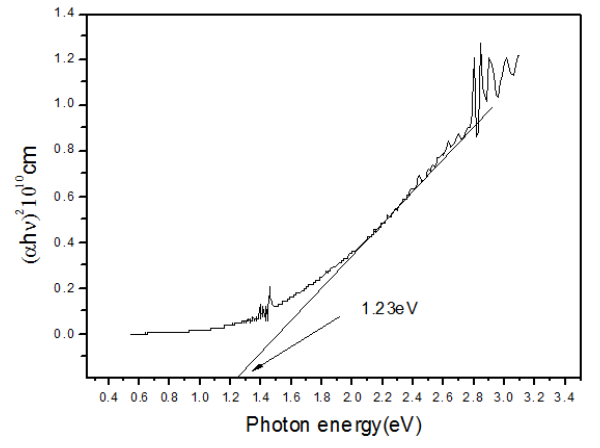

Fig. 12 Band gap energy of CIS film.

\section{CONCLUSION}

In this study, conventional CIGS solar cells, normal temperature and pressure, non-vacuum thin-film growth method simple process development is presented. High-temperature, high-vacuum and hazardous selenization process risks are reduced. Selenide separate process and Doctor-blade method using acetone solvent were used. Binder made of chloride series without necessary adjustment is affordable. Mixed precursor solution viscosity was adjusted at room temperature. Precursor thin film was formed on the substrate at atmospheric pressure CVD equipment. Chalcogenide CIS thin films through metal chlorides using a low vacuum heat treatment at without impurity phases could be synthesized. CIS / CIGS precursor thin film was coated on top of the substrate by Doctor-blade method selenization process with eliminating the chloride precursor solution by mixing with $\mathrm{SeCl}$. Coated CIS thin film showed reduction of the weight of the thin film at each temperature interval when annealing temperature increased. It is considered to be caused 
by the evaporation of the solvent, decomposition of the precursor and $\mathrm{Cl}$ gas evaporation. Metal chalcogenide, Metal chloride impurity phases such as pure chalcopyrite crystal structure without having a CIS thin film were formed $400^{\circ} \mathrm{C}$ and $500{ }^{\circ} \mathrm{C}$. XRD intensity of CIS thin-film concentration increased.

As you can see by these results CIS optical absorption layer could be obtained through a simple continuous process without adjusting viscosity of binder for CIS. The optical absorption layer by this technology should be expected to be saving of manufacturing cost and will be helpful for commercialization purpose.

\section{ACKNOWLEDGMENT}

Following are results of a study on the "Leaders in Industry-University Cooperation(LINC)" Project, supported by the Ministry of Education, Science \& Technology(MEST) and the National Research Foundation of Korea(NRF).

\section{REFERENCES}

[1] F. Hergert, R. Hock, A. Weber, M. Purwins, J. Palm, and V. Probst, J. phys. Chem. Solids., vol. 66, 1903-1907, 2005.

[2] National Science Foundation, "Research Applied to National Needs : Proc. Photovoltaics Conversion of Solar Energy for Terrestrial Application," Application, Report vol. I and II, Cherry Hill, New Jersey, NSF-RANN 74-103, 1975.

[3] D. Sawyer, Proc. NBS Workshop on Stability of Thin-Film Solar Cells and Materials, Gaithersburg, 1978.

[4] Q. Guo, S. J. Kim, M. Kar, W. N. Shafarman, R. W. Birkmire, E. A. Stach, R. Agrawal, and H. W. Hillhouse, Nano Lett, vol. 8, no. 9, 2008

[5] M. G. Panthani, V. Akhavan, B. Goodfellow et al., J. Am. Chem. Soc., vol. 130 , no. 49 , pp. 16770-16777, 2008.

[6] S. Wagner, J. L. Shay, P. Migliorato, and H. M. Dasper, Appl. Phys. Lett., vol. 25, pp. 434, 1974.

[7] K. R. Zweibel, H. S. Ullal, and R. L. Mitchell, Proc. 20th IEEE Photovoltaic Specialists Conf., IEEE., New York, pp. 1469-1476, 1988.

[8] I. Repins, M. A. Contreras, B. Egaas, C. DeHart, J. Scharf, C. L. perkins, B. To, and R. Noufi, Prog. Photovoltaics, vol. 16, no. 235 , 2008.

[9] A. M. Gabor and J. R. Tuttle, Solar Energy Materials and Solar Cells ch. $41 / 42$, pp. 247-260, 1996

[10] F. Hergert, R. Hock, A. Weber, M. Purwins, J. Palm, and V. Probst, $J$. phys. Chem. Solids., vol. 66, pp. 1903-1907, 2005.

[11] W. K. Kim, E. A. Payzant, T. J. Anderson, and O. D. Crisalle, Thin Solid Films, vol. 515, pp. 5837-5842, 2007.
[12] A. Kathalingam, T. Mahalingam and C. Sanjeeviraja, "Optical and structural study of electrodeposited zinc selenide thin films," Mat. Chem. Phys, vol. 106, no. 215, 2007.

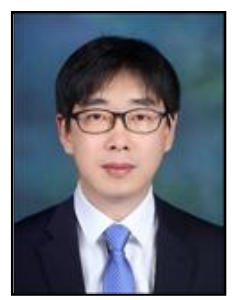

You Guk Lee obtained his master's degree from Department of Advanced materials and Engineering, Kumoh National Institute of Technology.

His Current research interests are Silicon solar cells, CIGS, Silicon processing.

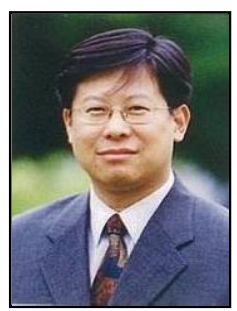

Dong Gu Lee is a professor. He received his Ph.D at Kumoh National Institute of Technology, Department of Advanced Materials and Engineering, South Korea.

His Current research interests are $\mathrm{MgO}$ nanocrystals, Silicon solar cells, electron optics simulations, carbon nanotube field emitters etc.

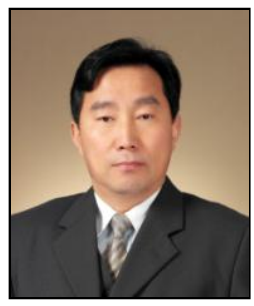

Sungjin Kim is a professor. He received his Ph.D at Kumoh National Institute of Technology, Department of Advanced Materials and Engineering, South Korea.

His Current research interests are $\mathrm{ZnO}$ nanostructures; Silicon, Dye Sensitized (DSSC), Organic-Inorganic solar cells, spark plasma sintering (SPS), photocatalyst, composite materials, Graphene.

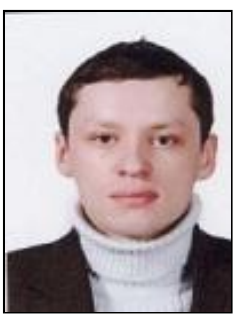

Amir Abidov is a doctorate student at Departmen of Advanced materials and Engineering, Kumoh National Institute of Technology.

His Current research interests are silicon solar cells, $\mathrm{DSSC}, \mathrm{TiO}_{2}$ photocatalyst and nanostructures, Graphene, composite materials by SPS organic-inorganic solar cells, hybrid solar modules. 